\title{
SPECIAL TECHNIQUE AS A CATEGORY OF LEGAL SCIENCE
}

\section{Ivan Kharaberiush}

\section{INTRODUCTION}

Development of technical support of law enforcement is based on the achievements of science and technology, however, is directly dependent on social progress, the degree of understanding by the public of threats from crime, and therefore the need to develop and apply adequate measures to counter it.

The application of scientific and technical means has such a significant value in the prevention, disclosure and investigation of crimes today that it is conducting law enforcement was in most cases impossible. First of all it concerns the issues of collecting and securing evidence, obtaining operational information, expert studies, the implementation of preventive, procedural and investigative actions that need detailed audiovisual documentation of events, and identify signs of illegal activity, inaccessible to ordinary human perception. In these cases, the application of scientific and technical means plays a crucial role, becoming the main instrument of combating crime.

In all areas of law enforcement are used and implemented advanced scientific and technological achievements. The continual growth of technical equipment of law enforcement bodies of Ukraine, the presence of law enforcement agencies that systematically use scientific achievements have led to the emergence of independent groups of technical means. They are grouped according to the main directions of the activities of law enforcement agencies (investigating, investigative, administrative and legal, security) ${ }^{1}$ and combined, we believe the common concept of "special equipment of law enforcement bodies".

However, in forensic science there are certain approaches to the classification of technology for the subjects of its use in law enforcement activities, namely the technical means of operational-investigative purpose are divided into operative equipment, special equipment, special means ${ }^{2}$. Further, the authors rightly point out the main difference from the operational forensic technology, which is not in the quality characteristics of technical means, and procedural and methodological aspects of its use.

1 Kharaberiush I.F. (2011) Protydija zlochynnosti zasobamy specialjnoji tekhniky: konceptualjnyj pidkhid [Combating crime by means of special vehicles: a conceptual approach]. Donecjk: Vyd-vo "Noulidzh", pp. 37-41. (in Ukrainian)

2 Pjaskovsjkyj V.V., Chornous Ju.M., Ishhenko A.V. ta in. (2015) Kryminalistyka: pidruchnyk [Forensics: a textbook]. K.: "Centr uchbovoji literatury", pp. 71-72. (in Ukrainian) 
The scientists also determined that the investigator, the Prosecutor or the court for the gathering and study of evidence use of weapons, means and methods that represent the achievements of natural and technical Sciences, forensic and operational techniques ${ }^{3}$. In this context, operational and forensic equipment are treated as separate divisions of jurisprudence.

Generally, the law enforcement technique, like any other object of scientific research, has a certain number of features, features, properties, and it is therefore natural in our legal science to determine the place and to clearly define this category. It is no secret that conceptual coherence is particularly important for jurisprudence, and without a developed conceptual apparatus through which the study of legal reality is deepened, one cannot count on the development of legal science.

\section{The concept of special equipment as a legal category}

The implementation of the new social policy and the construction of a rule of law in Ukraine, in turn, requires the modernization of the domestic legal system. On this basis, to ensure the effective activity of law enforcement agencies in combating crime in the context of today, an important issue is to conduct a scientific search for the solution of problems of the theory of law, and in our case, it is the definition of technology used in law enforcement as a scientific category, to our opinion, a separate discipline of legal science.

We support the view that tools, as a legal category, are tools for securing any activity and are of a general, cross-sectoral nature ${ }^{4}$. Accordingly, the technical means used in law enforcement as a separate kind of means should also be considered from these positions and refer to different branches of legal science.

Investigating the use of the term "technical means" and derivative phrases (scientific and technical means, special techniques, special technical means), we have found that they have such widespread use in scientific publications, legislative and regulatory acts that refer to the activities of dozens of ministries and agencies that perform completely different tasks that are not related to one another, that their use out of context (for example, for law enforcement) and without special comment loses all meaning.

To achieve the goal of our work, it is necessary to define the scientific concept of "forensic technology" as the most researched category, which gave impetus to the development of technical disciplines in other branches of legal

\footnotetext{
${ }^{3}$ Volobujev A.F., Danjshyn M.V., Ishhenko A.V. Kryminalistyka : pidruchnyk [Forensics: a textbook]. Kharkiv, p.113. (in Ukrainian)

${ }^{4}$ Olijnyk O.V. (2015) Administratyvno-pravovi zasoby zabezpechennja informacijnoji bezpeky [Administrative and legal means of ensuring information security]. Jurydychnyj visnyk, vol. 1(34), p. 66.
} 
science. In particular, the generalization of literature indicates that today more than 150 definitions of the concept of forensic science and forensic techniques have been proposed for about 70 variants of the system-structural structure of forensics ${ }^{5}$.

R.S. Belkin views forensic technology as a section of forensics that includes a system of scientific provisions and techniques, techniques and techniques developed to gather, investigate, and use evidence and other crime detection and prevention measures ${ }^{6}$. He emphasizes on the information approach and believes that it is not only the gathering of evidence, but also the accumulation and processing of information about the event being investigated, as well as the technical means and methods of crime detection and prevention.

Other authors at the present stage of the development of scientific and technical support for law enforcement activities determine that forensic technology is a section of forensics, which is a system of theoretical provisions formed by the results of the study of mechanisms of crime and their traces, which develops technical means, techniques and methods directed detection, recording, deletion and investigation of these traces for the purpose of detection, investigation and prevention of crimes ${ }^{7}$.

The development of forensic science has improved the concept of "forensic technology". On the one hand, this concept refers to the section of the science of forensic science, and on the other - the set of technical means used in criminal proceedings. As a section of science, forensic technology is a system of scientific provisions and recommendations that ensure the development of technical means (instruments, tools, devices and materials), as well as techniques and methods of their use for the purpose of investigating and preventing criminal offenses ${ }^{8}$. In addition, forensic technology is a separate section of the course "Forensics."

As part of forensic science, forensic technology consists not only of individual elements, that is, forensic theories, techniques, methods, teachings, etc., but also of particular branches of knowledge that form their own system ${ }^{9}$.

${ }^{5}$ Tkach Ju.D. (2004) Ponjattja i systemno-strukturna budova kryminalistyky [The concept and system-structural structure of forensics] (PhD Thesis), Odesa: Odessa State University of Internal Affairs.

${ }^{6}$ Belkin R.S. (2000) Kriminalisticheskaya entsiklopediya [Forensic Encyclopedia]. M.: Megatron XXI, p. 102. (in Russian)

7 Djomina K.E. (2017) Kriminalisticheskaja tehnika : uchebnik [Forensic Technology: Textbook]. M.: Juridicheskij institut MIIT, p. 9. (in Russian)

${ }^{8}$ Pjaskovsjkyj V.V., Chornous Ju.M., Ishhenko A.V. (2015) Kryminalistyka: pidruchnyk [Forensics: a textbook]. K.: "Centr uchbovoji literatury", p. 64. (in Ukrainian)

${ }^{9}$ Markusj V.O. Kryminalistyka: navchaljnyj posibnyk [Forensics: a textbook]. K.: Kondor, p. 53. (in Ukrainian) 
The system of forensic technology includes general provisions and specific fields (forensic photography and video recording, trasology, weapons science, habit, etc.), which are also ambiguously defined by scientists.

Having analyzed the scientific sources and opinions of a number of reputable researchers, we can say that forensic technology is a separate, independent part of forensics with its own system of scientific and technical provisions, principles and techniques, techniques and methods used to collect, process, investigating and providing forensic information for the purpose of investigating, detecting and preventing crimes. It has a special character in its purpose, which is manifested in the service of mainly criminal proceedings and is the main "supplier" of procedural information.

Another means of special purpose can be called operative technique. In our previous research ${ }^{10}$, we have shown that the category "operative technique", as an independent section of the theory of operational-search activity (OSA), has several meanings, such as: section science; the type of activity of the respective subjects in the use of operative and technical means for solving the problems of ARD and criminal process; section of the discipline "Special technique OSA".

Operational technology as a part of the theory of operational search activity and a component of the more general scientific concept of "special law enforcement equipment" has its own system, which includes general provisions and branches of operational technology (means of public information acquisition, means of secret information and means of providing operational search events).

True, we believe, is the opinion of P.P. Artemenko, defining the concepts of "operative technique" and "operative-technical means", emphasized that these means, by their direct purpose, purpose, constructive data, tactical features of use, personal normative regulation received "special" nature of use in the fight against crime. Together, these include specially designed or adapted to the specific needs of operational and search activities forensic, radio engineering, chemical, optical, phototechnical, sound recording and other scientific and technical means ${ }^{11}$.

We can state that forensic technology and operational technology have a special purpose and are correlated as equivalent independent parts of such sciences as forensic science and investigative activities, respectively.

${ }^{10}$ Kharaberjush I.F. (2017) Operatyvna tekhnika jak teoretyko-prykladna kateghorija operatyvno-rozshukovoji nauky [Operational technique as a theoretical and applied category of operative-search science]. Visnyk Mariupoljsjkogho derzhavnogho universytetu. Serija : Pravo, vol. 13. pp. 77-82.

${ }^{11}$ Artemenko P.P. (1988) Special'nye operativno-tehnicheskie sredstva: uchebnoe posobie [Special operational technical means: a training manual]. K., p. 4. (in Russian) 
Next, the scope of the concept of "special law enforcement equipment" needs to be clarified. To do this, we first conduct a semantic analysis of the essence and content of the term "special technique". It includes two components. Turning to the explanatory dictionaries, you can see that the concept of "special" means special, exclusively for something intended for, and also refers to a specific area of something inherent in any specialty ${ }^{12}$.

The term "technique" means, first, the totality of labor, tools, through which create something, secondly, the very machines, tools, devices, and, third, the set of knowledge, tools, methods, techniques used in any business ${ }^{13}$.

Thus, technology, on the one hand, is a set of means of activity created to carry out the processes of production and service of non-productive needs of society; on the other, the aggregate characteristic used to achieve the goal of skills, techniques and methods.

Contextual analysis of the essence and content of the term "special technique" makes it incorrect to use it out of context without defining the scope of this technique. In this case, belonging to "special" can be defined as a special design, technical capabilities and purpose of the device, device or device, yes, we believe, and special (specific) tactical methods of using these or other technical means, which were also emphasized by the authors mentioned above. In some cases, both the technical tool itself and the tactics of its application may be special.

With regard to "special law enforcement equipment" in its most general form, it refers to the totality of special techniques, tactics and methods of their effective lawful use in law enforcement activities.

To determine the scope of the concept, we apply the criterion selection method. Therefore, in order to define the scope of the concept of "special law enforcement equipment", it is necessary to select the criteria by which we will define it. From the relevant criteria in this case, we can distinguish the semantics of the phrase; system; structure; practical meaning; the similarity of the special equipment with the technique, the special equipment means with the scientific and technical means used in law enforcement activities.

We begin with a semantic analysis of the essence and content of the term "special technique", in which we first distinguish the meaning of the component element "technique". In this context, we agree that since any statutory requirement is expressed by means of a language (legal language) whose elementary structural unit is a word (term), it is important that the meaning and scope of such terms be clear to all subjects to whom it is

${ }^{12}$ Ozheghov S.Y. (1990) Slovarj russkogho jazyka [Dictionary of the Russian language]. M.: Rus. jaz., p. 753. (in Russian)

${ }^{13}$ Ozheghov S.Y. (1990) Slovarj russkogho jazyka [Dictionary of the Russian language]. M.: Rus. jaz., p. 795. (in Russian) 
addressed. legal prescription. One way to ensure the clarity of the statutory prescriptive and understandable intention of the legislator is to apply the legislative definitions in the texts of the relevant regulatory acts ${ }^{14}$.

The concept of "special technique" began to form in the second half of the twentieth century and related to the development of police science. Considering the use of technical means in law enforcement activities within the existing technical and legal support at the time, we can conclude that the authors have different approaches to the definition of the concept of "special technique". Some scientists narrowed it down to technical means only for operational and search purposes ${ }^{15}$, while others, recognizing this concept as generic, limited themselves only to technical means ${ }^{16}$, ignoring the methodology and tactics of their use, some of them, by defining special technology, took into account its components, but not enough, to our opinion, outlined the directions and forms of its use ${ }^{17}$ or did not take into account the structural changes that took place in the internal affairs bodies ${ }^{18}$.

The situation was no better by definition of the special techniques used in law enforcement, and in the recent works of scientists of Ukraine and other States.

R.V. Mukoida and A.O. Shelekhov define special equipment as the system hardware and relevant tactical techniques, which are applied by the bodies of internal Affairs in strict compliance with the law in the fight against crime, ensuring public order and perform other duties assigned to them. In this case, by technical means, they include: seven core classes: communication; alarms and industrial television; operational-technical means (tools unofficial photography and video recording, means of covert recording, search devices; night surveillance; special chemicals); reconnaissance and technical information protection; forensic engineering; information systems; means of individual

\footnotetext{
${ }^{14}$ Khvorostjankina A.V. Definiciji v zakonodavchykh tekstakh: pytannja teoriji [Definitions in legislative texts: questions of theory] Retrieved from : https://minjust.gov.ua/m/str_6669. Accessed (11.01.2020)

15 Bilenchuk P.D., Dubovyj O.P., Saltevsjkyj M.V., Tymoshenko P.Ju. (1998) Kryminalistyka: pidruchnyk dlja slukhachiv, ad'junktiv, vykladachiv vuziv systemy MVS Ukrajiny [Forensics: a textbook for students, adjuncts, teachers of higher education institutions of the Ministry of Internal Affairs of Ukraine]. K.: ATIKA, 416 p. (in Ukrainian)

${ }^{16}$ Levkov A.I., Anufriev P.M. (1979) Ispol'zovanie sredstv special'noj tehniki v rabote ugolovnogo rozyska: nauchno-prakticheskoe posobie [The use of special equipment in the criminal investigation: scientific and practical manual]. Omsk, 96 p. (in Russian)

${ }^{17}$ Dekshne V.I., Romanov A.P., Chekmarev Yu.V. (1986) Tehnicheskie sredstva i sistemy upravlenija $v$ organah vnutrennih del [Technical means and control systems in internal affairs bodies]. M., 82 p. (in Russian)

${ }_{18}$ Artemenko P.P., Voronin B.P., Voskresenskij G.M. (1982) Special'naja tehnika i ee primenenie: uchebnoe posobie [Special equipment and its application: study guide]. M., 348 p. (in Russian)
} 
protection and active defense ${ }^{19}$. We believe that such a definition does not take into account the latest achievements of science and clearly defines the classification of special equipment for activities of bodies of internal Affairs.

Some authors are not limited to the bodies of internal Affairs, and consider special equipment within all law enforcement agencies. They are under special equipment law enforcement understand the instruments, devices, equipment, machinery, chemicals and other man-made items (and their uses) that can be legitimately and effectively used when carrying out quickly-search actions, investigation, the maintenance of the regime in correctional institutions, law enforcement to prevent crime and solve crimes in cities and other settlements ${ }^{20}$.

Other scientists argue that special technique is a combination of technical tools and scientific methods to their legitimate use by authorized law enforcement officials with the aim of preventing and solving crimes, other offenses, criminals, detention of prisoners and persons suspected and accused of committing crimes ${ }^{21}$.

We see that the author considers the basic elements of the concept of "special technique of law enforcement"overburdened functional properties of these funds and open promising directions of improvement related to the emergence of new types of crimes.

The emergence of new types of crime in the information-communication sphere (the sphere of new information technologies) and the practical experience of combating these crimes has allowed us to include the means of special equipment specific anti - software and program-technical means ${ }^{22}$ that are fundamentally different from traditional media, classified as special.

Considering information support of fighting crime, we also saw the emergence of a very important means of collecting, stockpiling, storing, processing, searching and providing the necessary information - automated information retrieval systems and automated specialized systems ${ }^{23}$. They are

${ }^{19}$ Mukoida R.V., Shelekhov A.O. (2013) Specialjna tekhnika v orghanakh vnutrishnikh sprav [Special equipment in law enforcement agencies]. Odesa: ODUVS, p. 5. (in Ukrainian)

${ }^{20}$ Pudakov E.R., Japparov R. R. (2017) Special'naja tehnika pravoohranitel'nyh organov [Special law enforcement technique]. Ufa: Izd vo BIST (filial) OUP VO "ATiSO", p. 5. (in Russian)

${ }^{21}$ Bystrjakov, E.N., Savel'eva M.V., Smushkin A.B. (2018) Special'naja tehnika [Special equipment]. Moskva : JuSTICIJa, p. 10. (in Russian)

${ }^{22}$ Kharaberiush I.F., Macjuk V.Ya., Nekrasov V.A., Kharaberiush O.I. (2007) Vykorystannja operatyvno-tekhnichnykh zasobiv u protydiji zlochynam, shho vchynjajutjsja u sferi novykh informacijnykh tekhnologhij [Use of operational and technical means in combating crimes committed in the field of new information technologies]. K. : KNT, pp. 55-56. (in Ukrainian)

${ }^{23}$ Kharaberiush I.F. Specialjna tekhnika jak chynnyk vplyvu na stan operatyvnoji obstanovky terytoriji obslughovuvannja pidrozdilamy karnogho rozshuku [Special equipment as a factor in 
specific hardware and software systems that constitute, in our opinion, a separate group of special equipment under the generalizing term "automated systems".

On the basis of generalization of research results in the field of intelligence and intelligent systems ${ }^{24}$, we argue that this is a promising process of providing information systems that are being used to fight crime, the properties of intelligence: communication skills; analytical capabilities; ability to constantly learn; adaptability; ability to self-evaluation; creativity.

We believe that intelligent systems is a more advanced level of automated systems, which should also be a separate group of special equipment that can significantly enhance the effectiveness of law enforcement.

Paying attention to hardware the concept of "special equipment of law enforcement bodies", take a closer look at its methodological component, in which we have to determine the place of modern information technology.

Try to understand what is the essence of the phenomenon of "information technology" for law enforcement, what meaning they have, what areas most effectively use them to improve the law enforcement can be, and what is the prospect of the development of information technology in law enforcement.

The Basic principles of information society development in Ukraine for 2007-2015 stated that one of the main priorities of Ukraine is striving to build focused on the interests of the people, open to all and aimed at development of information society, which is based on the concepts and programs of Informatization, the creation of various information and communication technologies and the national information-analytical systems of different levels and functions.

We can also see that in the context of global integration and stiff international competition the main arena of collision and struggle to push and pull of national interests of States becomes an information space. Modern information technologies enable States to implement their own interests without using military force, to weaken or to cause significant harm to the competitive security of the state, which does not have an effective system of protection from the negative effects of information.

Among the objective factors contributing to the modification of the stereotypes of human activity is the computerization of all spheres of its activities and the permanent growth of the volumes of information, and this in

influencing the operational situation of the territory of service of units of criminal investigation department], Visnyk Lughansjkogho derzhavnogho universytetu vnutrishnikh sprav imeni E.O. Didorenka, vol. 2, no 2, pp, 150-151.

${ }^{24}$ Kharaberiush I.F. (2018) Intelektualjni systemy v pravookhoronnij dijaljnosti [Intellectual systems in law enforcement]. Visnyk Mariupoljsjkogho derzhavnogho universytetu. Serija : Pravo, vol. 16, no. 1, pp. 39-45. 
turn requires the use of professional law enforcement modern achievements of scientific and technological progress, one of which is information technology.

Considering the term "technology" in a broad sense, we mean a body of knowledge that can be used for the production of goods and services from economic resources. In the narrow sense is a set of methods of transformation of substance, energy and information in the process of production, handling and processing of materials, Assembly of finished products, quality control, management ${ }^{25}$. The term "technology" includes methods, techniques, modes of operation, sequence of operations and procedures, it is closely linked with the applicable tools, equipment, tools, materials used.

Any technology provides:

- the subject of labor (the technological impact, technological object),

- means of labour (technology),

media processing functions (worker, team, etc.),

- the level of technological development of society.

The term "information" means that, with respect to information ${ }^{26}$. Therefore, the "information technology"- technology that is designed and for information. The subject of labor information technology is information and information resources. Labour means in our case are the computer equipment and telecommunications, and in the future - the means of information processing and communication corresponding to the level of technological development of society. Media processing functions can be computer equipment and telecommunications, automated information systems or law enforcement officials.

Thus, information technology is a set of methods, techniques, processing methods, processing or transmission of information and information resources computing and telecommunications, automated information systems or directly by employees to obtain the necessary information of product, control or manage certain processes.

Information resources (objects of accounting) information systems of law enforcement are objectively combined set of information directly on persons, events (criminal and administrative offences), the extraordinary event, which accumulates in the process of business activities of law enforcement agencies in the volume, structure and manner determined by the tasks assigned to them in accordance with applicable law.

${ }^{25}$ Busel V.T. (2001) Velykyj tlumachnyj slovnyk suchasnoji ukrajinsjkoji movy [A great explanatory dictionary of modern Ukrainian]. K.: Irpenj: VTF "Perun", p. 1245. (in Ukrainian)

${ }^{26}$ Nechvolod L.I. (2007) Suchasnyj slovnyk inshomovnykh sliv [Modern dictionary of foreign words]. Kharkiv: TORGhSIN PLJuS, p. 270. (in Ukrainian) 
From the above we can define the term "special equipment of law enforcement bodies". A special technique of law enforcement agencies are the totality of special equipment and methods of their lawful use in order to perform the tasks of law enforcement. Special equipment according to this definition is technical, software, hardware and software, special devices, substances, automated and intelligent systems. Methodological basis of special techniques are scientifically based tactics, techniques, and information technology.

\section{System-structural structure of special equipment of law enforcement agencies}

Having defined the conceptual apparatus, consider a system-structure of the special equipment law enforcement as a scientific category according to the selected criteria.

The system is a set of qualitatively defined elements, between which there is a natural relationship or a relationship. Consistency is an objective property inherent in every physical object, phenomenon, event. Special equipment as a branch of knowledge represents the totality of knowledge, which in a certain sequence according to their importance, relationships and relationships.

Generalization of the accumulated in the process of historical development of scientific data is one of the primary stages of the development of science as a separate branch of knowledge, and its data in a logically sound system testifies to the independence and maturity of the science, the level of theoretical generalization as embodied in its subject phenomena of objective reality which are studied by this science. The system of any science is not determined by an arbitrary assignment of those or other questions in the same discipline, and by combining them on the basis of internal unity and objective relations. Like every science, the special equipment law enforcement has its own system, which has evolved over time and requires a clear definition with regard to the requirements of modernity.

We already know - the concept of "special equipment" is General and used legislative and normative acts regulating the activities of many ministries and departments. Similarly, the term "special equipment of law enforcement bodies"brings together all the technical tools that are used in law enforcement and studied the separate academic disciplines. We in our previous works ${ }^{27}$ and individual researchers in their studies ${ }^{28}$ the basis for the interdisciplinary division

27 Kharaberiush I.F. (2011) Protydija zlochynnosti zasobamy specialjnoji tekhniky: konceptualjnyj pidkhid [Combating crime by means of special vehicles: a conceptual approach]. Donecjk: Vyd-vo "Noulidzh", pp. 37-41. (in Ukrainian)

${ }_{28}$ Artemenko P.P., Voronin B.P., Voskresenskij G.M. (1982) Special'naja tehnika i ee primenenie: uchebnoe posobie [Special equipment and its application: study guide]. M., pp. 15-16. (in Russian) 
of special equipment used the professional orientation of its use - investigative, investigative, legal and administrative. This is because, firstly, there is a legal regulation of the use of technology in each of these areas law enforcement. Second, a scientific base on the theory and practice of using scientific-technical means. Thirdly, accumulated extensive practical experience in the use of technology that helped to create a methodological basis for use of these funds in each of the abovementioned areas of law enforcement.

The term "special equipment of law enforcement bodies", by analogy with the forensic technique of ${ }^{29}$ and surgical technique ${ }^{30}$, first, the section refers to such Sciences as criminology, investigative and administrative activity; secondly, as a set of special techniques and methods of their use in law enforcement; third, as an academic discipline "Special equipment of law enforcement bodies".

Special equipment law enforcement as an interdisciplinary field of legal science is a system of scientific statements and recommendations, creating conditions for the development of technical tools (forensic, technical, operational, organizational, security), and scientific methods, techniques and information technologies with the aim of combating crime by law enforcement.

In our opinion, the system of special equipment law enforcement should be elements, which include General provisions and the special techniques of law enforcement. General provisions should define the basic concepts, system, principles of usage, tasks of special equipment, the General characteristics of the special equipment, techniques and methods of their application, legal regulation at the decision of tasks of law enforcement.

Industry special equipment of law enforcement bodies, as we have already specified, should consist of the main directions of its use in law enforcement. On directions of use it can be considered in relation to investigative activities and forensic technology, investigative activities and operational equipment, administrative - organizational machinery.

In turn, funds special equipment, we believe, can be classified according to three criteria: direction of use; sources; purpose.

On directions of use of means of special equipment can be divided into tools forensic, operational, organizational and security equipment.

${ }^{29}$ Chaplynsjkyj K.O., Luskatov O.V., Pyrigh I.V., Pletenecj V.M., Chaplynsjka Ju.A. (2017) Kryminalistyka [Criminalistics]. Dnipro : Dniprop. derzh. un-tvnutr. sprav ; LiraLTD. (in Ukrainian)

${ }^{30}$ Kharaberjush I.F. (2017) Operatyvna tekhnika jak teoretyko-prykladna kateghorija operatyvno-rozshukovoji nauky [Operational technique as a theoretical and applied category of operative-search science]. Visnyk Mariupoljsjkogho derzhavnogho universytetu. Serija : Pravo, vol. 13. pp. 77-82. 
Regarding the sources of funds special techniques that are used in law enforcement activities can be divided into three large groups: General use (adapted) for General use with minor alterations (modified) and specially designed (unique).

On purpose funds special equipment can be considered, given their technical capabilities, which are used to implement forms of law enforcement, namely:

- judicial;

- pre-trial investigation;

- investigative;

- intelligence;

- counterintelligence;

- control and oversight;

- administrative, security.

By purpose, we believe they are divided into: means of fixing information; management tools (communications, language enhancement, systems for collecting, accumulating and analyzing information, etc.); technical means of protection; search engine; means of observation and control; specialty chemicals; special protection means; means and systems of silently obtaining information and traces of illegal activity, etc.

Based on the definition of "special law enforcement agencies" defined by us, and taking into account the explanations provided by scientists regarding the scientific and technical means used in the criminal process, - "a set of devices, devices, apparatus, tools and materials used in accordance with the law specially authorized individuals to achieve a scientifically sound result that would contribute to the protection of the rights and legitimate interests of participants in criminal proceedings, full and rapid disclosure of crimes and exposure of persons guilty of their commission" 31 we can correlate them. In this context, the terms "scientific and technical means" are synonymous with "means of special technology" - technical, software and software tools, special devices, substances, automated and intellectual systems that are included as a specific component of scientific and technical means.

\section{CONCLUSIONS}

Summing up, we can say that the special technique of law enforcement agencies are the totality of special equipment and methods of their lawful use

31 Punda O.O. (2002) Vykorystannja danykh, oderzhanykh v rezuljtati zastosuvannja naukovo-tekhnichnykh zasobiv, dlja dokazuvannja $\mathrm{v}$ kryminaljnomu procesi [Use of data obtained as a result of the use of scientific and technological means for proving in criminal proceedings] (PhD Thesis), K. 
in order to perform the tasks of law enforcement. The development of special techniques of law enforcement, as a component of scientific-technical means, based on the achievements of science and technology, however, is directly dependent on social progress, the degree of understanding by the public of threats from crime, and therefore the need to develop and apply adequate measures to counter it. In this process, the implemented social features special equipment, such as cognitive, creative, educational, promotional, etc. active To a certain extent for the development of scientific and technical support of law enforcement with an innovative activity that is expressed by the formula development - testing - implementation - practice.

Special equipment of law enforcement bodies is an interdisciplinary legal theory, the components of which are studied by such Sciences as criminal process and criminalistics, operational-search activity, administrative law and process. It is made up of General provisions and individual industries.

Industry special equipment of law enforcement agencies consist of the main directions of its use in law enforcement and are divided into criminalistic equipment, operational equipment and office equipment.

Funds for special equipment are classified according to three criteria: direction of use; sources; purpose. On directions of use of means of special equipment are divided into tools forensic, operational, organizational and security equipment. Regarding the sources of funds special techniques that are used in law enforcement activities, divided into three large groups: General use (adapted) for General use with minor alterations (modified) and specially designed (unique). According to the designation they are divided into: a means of recording information; means of organization of management (communication, speech amplification system of collection, accumulation and analysis of information); technical security equipment; search equipment; monitoring and control; special chemicals; special protection; and secret information and traces of illegal activity.

\section{SUMMARY}

The correlation of forensic technology and operational technology among themselves and with special The equipment of law enforcement agencies was investigated. It is shown that the constant growth of technical equipment of the law enforcement agencies of Ukraine and the presence of law enforcement structures led to the emergence of independent groups of technical means. It is emphasized that the forensic technique has a special character for its purpose, manifested in the maintenance of the main criminal process to obtain procedural information. It is proved that operational technology, as a section of the theory of operational-search activity and a component of the more general scientific concept of "special technology of law enforcement 
agencies", has its own system and correlates with the forensic technique as equivalent categories of legal science. The emergence of a very important means of collecting, accumulating, storing, processing, searching and providing the necessary information is shown - automated information retrieval systems, automated specialized systems and intelligent systems that make up a separate group of special equipment. It is proved that the methodological basis of special equipment is scientifically based tactical techniques, methods and information technology. Special equipment of law enforcement agencies as an interdisciplinary branch of legal science is a system of scientific regulations and recommendations, create conditions for the development of technical tools (forensic, operational, organizational, security), as well as scientifically based methods, techniques and information technology to counter crime law enforcement agencies. The system of special equipment of law enforcement agencies consists of elements that include general provisions and branches of special equipment of law enforcement agencies. Branches of special equipment of law enforcement agencies consist of the main directions of its use in law enforcement, namely: with respect to investigative activities - forensic technology, operational search activities operational technology, administrative activities - organizational technology. It is proved that the special technique of law enforcement and forensic technology are both common and particular, respectively.

\section{REFERENCES}

1. Kharaberiush I.F. (2011) Protydija zlochynnosti zasobamy specialjnoji tekhniky: konceptualjnyj pidkhid [Combating crime by means of special vehicles: a conceptual approach]. Donecjk: Vyd-vo "Noulidzh" (in Ukrainian)

2. Pjaskovsjkyj V.V., Chornous Yu.M., Ishhenko A.V. (2015) Kryminalistyka: pidruchnyk [Forensics: a textbook]. Kyiv : "Centr uchbovoji literatury", pp. 71-72. (in Ukrainian)

3. Volobujev A.F., Danjshyn M.V., Ishhenko A.V. Kryminalistyka : pidruchnyk [Forensics: a textbook]. Kharkiv, p. 113. (in Ukrainian)

4. Olijnyk O.V. (2015) Administratyvno-pravovi zasoby zabezpechennja informacijnoji bezpeky [Administrative and legal means of ensuring information security]. Jurydychnyj visnyk, vol. 1 (34), p. 66.

5. Tkach Ju.D. (2004) Ponjattja $i$ systemno-strukturna budova kryminalistyky [The concept and system-structural structure of forensics] (PhD Thesis), Odesa: Odessa State University of Internal Affairs.

6. Belkin R.S. (2000) Kriminalisticheskaya entsiklopediya [Forensic Encyclopedia]. Moskva: Megatron XXI, p. 102. (in Russian)

7. Djomina K.E. (2017) Kriminalisticheskaja tehnika : uchebnik [Forensic Technology: Textbook]. Moskva : Juridicheskij institut MIIT, p. 9. (in Russian) 
8. Markusj V.O. Kryminalistyka: navchaljnyj posibnyk [Forensics: a textbook]. Kyiv: Kondor, p. 53. (in Ukrainian)

9. Kharaberiush I.F. (2017) Operatyvna tekhnika jak teoretyko-prykladna kateghorija operatyvno-rozshukovoji nauky [Operational technique as a theoretical and applied category of operative-search science]. Visnyk Mariupoljsjkogho derzhavnogho universytetu. Serija : Pravo, vol. 13. pp. 77-82.

10. Artemenko P.P. (1988) Special'nye operativno-tehnicheskie sredstva: uchebnoe posobie [Special operational technical means: a training manual]. Kyiv. (in Russian)

11. Ozheghov S.Y. (1990) Slovarj russkogho jazblka [Dictionary of the Russian language]. M.: Rus. jaz., p. 753. (in Russian)

12. Khvorostjankina A.V. Definiciji v zakonodavchykh tekstakh: pytannja teoriji [Definitions in legislative texts: questions of theory] URL: : https://minjust.gov.ua/m/str_6669. Accessed (11.01.2020)

13. Bilenchuk P.D., Dubovyj O.P., Saltevsjkyj M.V., Tymoshenko P.Yu. (1998) Kryminalistyka: pidruchnyk dlja slukhachiv, ad'junktiv, vykladachiv vuziv systemy MVS Ukrajiny [Forensics: a textbook for students, adjuncts, teachers of higher education institutions of the Ministry of Internal Affairs of Ukraine]. Kyiv: ATIKA. (in Ukrainian)

14. Levkov A.I., Anufriev P.M. (1979) Ispol'zovanie sredstv special'noj tehniki $v$ rabote ugolovnogo rozyska: nauchno-prakticheskoe posobie [The use of special equipment in the criminal investigation: scientific and practical manual]. Omsk, 96 p. (in Russian)

15. Dekshne V.I., Romanov A.P., Chekmarev Yu.V. (1986) Tehnicheskie sredstva $i$ sistemy upravlenija $v$ organah vnutrennih del [Technical means and control systems in internal affairs bodies]. Moskva, 82 p. (in Russian)

16. Artemenko P.P., Voronin B.P., Voskresenskij G.M. (1982) Special'naja tehnika i ee primenenie: uchebnoe posobie [Special equipment and its application: study guide]. Moskva, 348 p. (in Russian)

17. Mukoida R.V., Shelekhov A.O. (2013) Specialjna tekhnika $v$ orghanakh vnutrishnikh sprav [Special equipment in law enforcement agencies]. Odesa: ODUVS. (in Ukrainian)

18. Pudakov E. R., Japparov R. R. (2017) Special'naja tehnika pravoohranitel'nyh organov [Special law enforcement technique]. Ufa : Izd vo BIST (filial) OUP VO “ATiSO”. (in Russian)

19. Bystrjakov, E.N., Savel'eva M.V., Smushkin A.B. (2018) Special'naja tehnika [Special equipment]. Moskva : JuSTICIJa, p. 10. (in Russian)

20. Kharaberiush I.F., Macjuk V.Ja., Nekrasov V.A., Kharaberiush O.I. (2007) Vykorystannja operatyvno-tekhnichnykh zasobiv $u$ protydiji zlochynam, shho vchynjajutjsja u sferi novykh informacijnykh tekhnologhij 
[Use of operational and technical means in combating crimes committed in the field of new information technologies]. Kyiv : KNT, pp. 55-56. (in Ukrainian)

21. Kharaberiush I.F. Specialjna tekhnika jak chynnyk vplyvu na stan operatyvnoji obstanovky terytoriji obslughovuvannja pidrozdilamy karnogho rozshuku [Special equipment as a factor in influencing the operational situation of the territory of service of units of criminal investigation department], Visnyk Lughansjkogho derzhavnogho universytetu vnutrishnikh sprav imeni E.O. Didorenka, vol 2, no 2, pp, 150-151.

22. Kharaberiush I.F. (2018) Intelektualjni systemy v pravookhoronnij dijaljnosti [Intellectual systems in law enforcement]. Visnyk Mariupoljsjkogho derzhavnogho universytetu. Serija : Pravo, vol. 16, no. 1, pp. 39-45.

23. Busel V.T. (2001) Velykyj tlumachnyj slovnyk suchasnoji ukrajinsjkoji movy [A great explanatory dictionary of modern Ukrainian]. Kyiv: Irpenj: VTF "Perun", p. 1245. (in Ukrainian)

24. Nechvolod L.I. (2007) Suchasnyj slovnyk inshomovnykh sliv [Modern dictionary of foreign words]. Kharkiv: TORGhSIN PLJuS, p. 270. (in Ukrainian)

25. Chaplynsjkyj K.O., Luskatov O.V., Pyrigh I.V., Pletenecj V.M., Chaplynsjka Ju.A. (2017) Kryminalistyka [Criminalistics]. Dnipro : Dniprop. derzh. un-tvnutr. sprav ; LiraLTD. (in Ukrainian)

26. Punda O.O. (2002) Vykorystannja danykh, oderzhanykh v rezuljtati zastosuvannja naukovo-tekhnichnykh zasobiv, dlja dokazuvannja v kryminaljnomu procesi [Use of data obtained as a result of the use of scientific and technological means for proving in criminal proceedings] $(\mathrm{PhD}$ Thesis), Kyiv.

Information about the author: Ivan Kharaberiush, Doctor of Law, Professor, Professor at the Department of Law and Public Administration, Mariupol State University 129a, Stroiteley pr., Mariupol, 87500, Ukraine ORCID ID: orcid.org/0000-0002-4968-5421 